\title{
Patients get viral infections: so, do vines
}

\author{
Shaun R. McCann ${ }^{1}$
}

Received: 18 September 2019 / Revised: 1 October 2019 / Accepted: 1 October 2019 / Published online: 23 October 2019

(c) Springer Nature Limited 2019

Vaccination, hemopoietic cell transplantation and phylloxera.

'A man may surely be allowed to take a glass of wine by his own fireside'. Richard Brinsley Sheridan. (1751-1816). Irish playwright, poet and satirist.

[In 1776, Sheridan became a manager of the Drury Lane Theatre in London, and remained in that position until the theatre burned down in 1809. Legend has it that Sheridan was drinking wine while watching the fire, and, when questioned about it, he quipped the above.]

Vaccination against measles is in the news again. Many people refuse vaccination against measles and a number of putative reasons have been offered to explain this phenomenon [1]. Some celebrities, who know absolutely nothing about public health, are also making statements decrying vaccination. The frightening thing is that some people give more credence to celebrities' comments about vaccination than to statements issued by the Centre for Disease Control. Few young doctors have ever seen a case of measles as it has been eradicated in many jurisdictions. Measles, of course, is a very serious illness and can cause severe secondary infection. It is particularly feared in the immunocompromised population and may cause mortality. Some states are making measles vaccination mandatory before children can enter school and my own memory is that my son was unable to attend the University of Minnesota Child Development Centre in 1974 unless we could produce a certificate demonstrating his immune status to measles.

There is a significant literature on vaccination schedules in recipients of hemopoietic cell transplants (HCT) [2, 3]. However, what about staff? This may be particularly

Shaun R. McCann

shaunrmccann@gmail.com

1 Emeritus Haematology, University of Dublin, Trinity College, Dublin, Ireland important in paediatric transplant/leukaemia units. In a recent review Pochon and Voigt [4] mention numerous viruses including influenza, parainfluenza, human metapneumovirus, rhinovirus, coronavirus, bocavirus and respiratory syncytial virus most of which have been documented to cause respiratory infection in children who have received HCT. Other viruses including adenovirus, HHV6, BKV and VZV may cause problems in adults as well as children. However, the literature on staff vaccinations in HCT units is relatively sparse (personal communication from Professor Jane Apperley and Professor Per Ljungman). The current edition of the EBMT handbook does not mention vaccination policies for staff members in paediatric haemopoietic cell transplant units [5]

Can vines suffer from viral infection? Yes, they can. Viral infection due to the GLRaV-3-leafroll virus was a major cause of poor crops especially in South Africa. The virus is spread by mealybugs which are insects of the Pseudococcidae family. This problem was predominantly seen in the apartheid days and happily due to ripping up of infected plants is no longer such a problem. However, the infectious disease which is most infamous and feared by wine makers is that caused by the aphid known as phylloxera vastatrix (Fig. 1). The story is complicated and investigating it and finding effective treatment was very

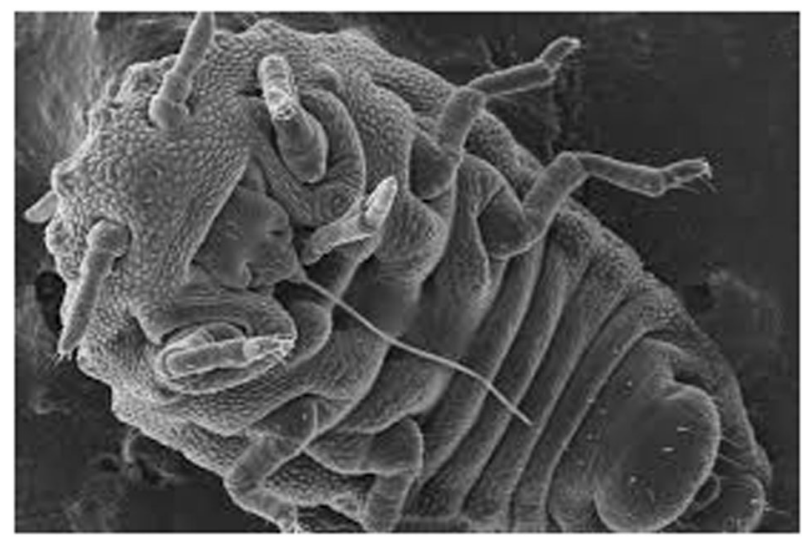

Fig. 1 Grape Phylloxera (Daktulosphaira vitifoliae). Infected vines often get fungal infection 


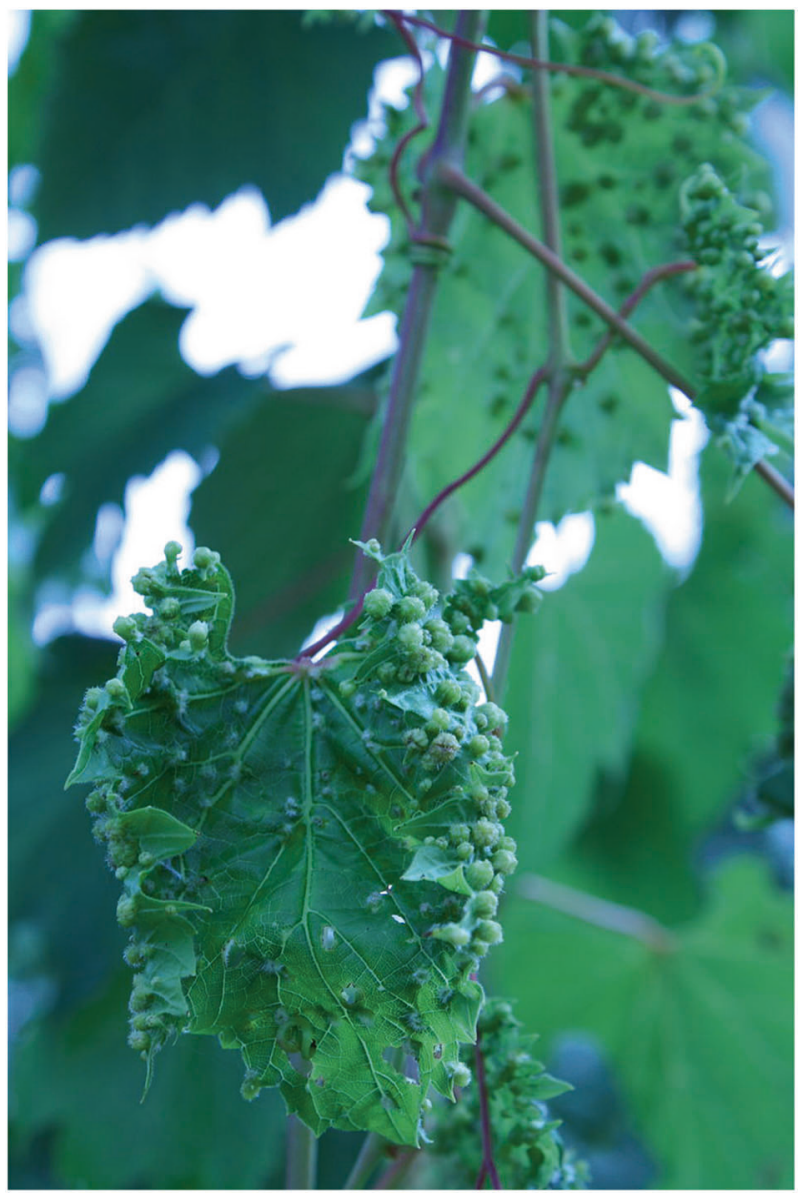

Fig. 2 Galls on infected vine leaves. Vine roots are infected with the root-feeding form, the radiciole. The roots swell and grow into a structure called a gall

difficult. As Goode says [6] the devastation caused by phylloxera was so great that it threatened to eradicate viticulture. Most vines in Europe were vitis vinifera which were highly susceptible to phylloxera, whereas American vines were resistant. One of the important people in the story was the English entomologist Charles V Riley (he became a naturalised American citizen and died in the United States) who identified the phylloxera aphid in America as the same insect that caused devastation in Europe. By 1830, American vines were beginning to be imported into Europe. The irony is that the imported vines which were resistant to phylloxera actually were the source of introducing it into Europe. Pasteur's theories had not yet been published and some strange ideas existed. According to Goode some people in Tuscany thought that railway trains were responsible for the infection and many kilometres of train tracks were torn up! Monsieur Borty in Southern France in 1862 received vines from New York and by 1868 the whole of the Southern Rhône was affected by phylloxera. The aphid soon spread to Portugal, Spain, Italy, Australia and Champagne in 1890. Jules Emile Planchon, appointed by the French government, dug up vines and saw wingless insects happily eating the vine roots.

Phylloxera has a complicated life cycle. It sucks nutrients from the phloem (I knew those botany classes would be useful someday) and reproduces asexually. The root form is exclusively female (radicole), punctures the roots and injects saliva. The eggs hatch and become crawlers which move along the roots and can be spread by wind or on farmers boots/hands. Asexual forms can develop on vine leaves where they are called galls Fig. 2. How to counteract this catastrophe? It eventually became clear (Henri Bouchet gets the credit in 1874) that grafting American rootstock retained the full character of vitis vinifera but was resistant to phylloxera. The rest is history.

Unfortunately, we can't vaccinate against phylloxera but even in this post-Enlightenment era people continue to ignore one of the unequivocally best strategies in medicine...vaccination.

\section{Compliance with ethical standards}

Conflict of interest The author declares that he has no conflict of interest.

Publisher's note Springer Nature remains neutral with regard to jurisdictional claims in published maps and institutional affiliations.

\section{References}

1. McKee C, Bohannon K. Exploring the reasons behind parental refusal of vaccines. J Pediatr Pharm Ther. 2016;21:104-9.

2. Carpenter PA, Englund JA. How I vaccinate blood and marrow transplant recipients. Blood. 2019;127:2824-32.

3. Ljungman P, Cordonnier C, Einsele H, Englund J, Machado CM, Storek J, et al. Vaccination of haematopoietic cell transplant recipients. Bone Marrow Transp. 2009;44:521-6.

4. Pochon C, Voigt S. Respiratory virus infections in hematopoietic cell transplant recipients. Front. Microbiol. 2019. https://doi.org/10. 3389/fmicb.2018.03294.\#.

5. Carreras E, Dufour C, Mohty M and Kröger N Fondation José Carreras, editors. The EBMT handbook. Hematopoietic stem cell transplantation and cellular therapies. Springer Open. 2019. ISBN 978-3-030-02277-8.

6. Goode J. Wine science: the application of science in winemaking. London UK: Octopus Publishing Group Ltd; 2005. ISBN 1 8400968-3. 